\title{
Theoretical Basis for the Measurement of Small Differences in the Length of the Cell Cycle between Two Cell Populations
}

\author{
Juan Sebastian Yakisich* $^{*}$
}

Karolinska Huddinge Hospital, Karolinska Institute, Department of Clinical Neuroscience, Division of Neurology R54, Stockholm, SE-141 86, Sweden

\begin{abstract}
The length of the cell cycle $\left(\mathrm{T}_{\mathrm{C}}\right)$ is a tight regulated process and is important for proper development and homeostasis. Although several methods are available for estimating the duration of the cell cycle, it is difficult to determinate small differences of $\mathrm{T}_{\mathrm{C}}$ between two different cell populations due to biological and/or experimental variability. A novel strategy based in co-cultivation of two cell strains followed by a series of dilution and propagation of the culture will allow the quantification of very small differences in the length of two cell populations at resolution levels not possible at present with current methods. This is achieved by a separation of the endpoint variable measured to compare between two cell populations. The theoretical basis of this approach is discussed in the context of published experimental data and simulation of idealized experiments using virtual strains of different cell cycle length.
\end{abstract}

Keywords: Cell cycle length, method, co-cultivation, cell population, single cell measurement, proliferation, cell cycle kinetics.

\section{INTRODUCTION}

Alterations in the length of the cell cycle $\left(\mathrm{T}_{\mathrm{C}}\right)$ might confer different growth properties. For unicellular organisms, a shorter time to divide gives cells growth advantage. In theory, the faster growing strain can overgrow the slower growing strain that would eventually disappear. For multicellular organisms a fine regulation of the length of the cell cycle is required for proper development and homeostasis. Indeed, progressive lengthening of the cell cycle during development has been observed in several organisms [1-5]. The most remarkable example occurs during Drosophila development where the $T_{C}$ varies from few minutes to $24 \mathrm{hrs}$ [5]. Evolutionary modifications of $T_{C}$ have also been reported among species [6,7]. Dysregulation of the $T_{C}$ might be related to several diseases. For instance, it was recently reported that glioma stem cells have elongated cell cycle compared to non-stem glioma cells. This difference might confer differential properties including increased radioresistance [8]. Therefore, accurate measurement of the length of the cell cycle as well as accurate determination of cell cycle differences between cell types are important parameters for a broad range of applications and have important implications for biology and medicine.

There are several methods to establish $\mathrm{T}_{\mathrm{C}}$ that rely on cell cycle synchronization and/or population doubling time using either cell count or DNA content and direct observation of single cells by time lapse video microscopy [9-13]. Each method has theoretical and practical limitations and a detailed description of each assay is beyond the scope of this manuscript. For convenience, methods are divided into two

*Address correspondence to this author at the Karolinska Huddinge Hospital, Karolinska Institute, Department of Clinical Neuroscience, Division of Neurology R54, Stockholm, SE-141 86, Sweden; Tel: 468585 89 533; Fax: 46858587 080; E-mail: sebastian.yakisich@ki.se categories: a) Methods Based in Cell Population (MsBCP; e.g. cell culture, in vivo labelling with DNA precursors) and, b) Methods Based in Single Cell (MsBSC; e.g. time lapse video microscopy).

MsBCP have the advantage to averaging the small variation in the $T_{C}$ of individual cells and the $T_{C}$ measured should be a very good average estimation. However, experimental variability is an important limitation and makes MsBCP not suitable for comparing cell types with a small cell cycle length difference $\left(\Delta \mathrm{T}_{\mathrm{C}}\right)$. One example analysing published data illustrates this point: Table $\mathbf{S} 1$ shows the $T_{C}$ of the retinal cells by published experiments ([1]; data from Table 3). The $\mathrm{RT}_{\mathrm{C}}$ (See glossary for the nomenclature used in this manuscript) for two consecutive days can be calculated by dividing the $\mathrm{T}_{\mathrm{C}}$ at one particular day over the $\mathrm{T}_{\mathrm{C}}$ from the next day. As shown in Table $\mathbf{S 1}$, the $\mathrm{RT}_{\mathrm{C}}$ varies daily (range 0.904 to 0.830 ). The data from Alexiades and Cepko, demonstrate a daily variation in the $T_{C}$ of retinal cell during development indicating that there are factors controlling (elongating) the $\mathrm{T}_{\mathrm{C}}$ in a daily basis. The conclusion of this experiment is that cells from E14 have a $T_{C}$ shorter than E15. However, by comparing only two cell populations, it will be very difficult to find a statistical significant difference between E14 vs. E15 $\left(\mathrm{RT}_{\mathrm{C}}=0.904\right)$ but it will be easy for $\mathrm{E} 14 v s . \mathrm{E} 21\left(\mathrm{RT}_{\mathrm{C}}=0.442\right)$. Thus, the closer the $\mathrm{RT}_{\mathrm{C}}$ to 1 , the more difficult will be to reach statistical significance (See Table S1 and accompanying figure). This evaluation suggests that MsBCP are not suitable for estimating small $\Delta \mathrm{T}_{\mathrm{C}}$.

Historically, time lapse video microcoscopy (TLVM probably the only MBSC suitable to estimate $\mathrm{T}_{\mathrm{C}}$ in single cell-) was introduced to study variability in generation time and showed that the $T_{C}$ of individual cells varies from generation to generation and of course from cell to cell [10]. Analysis of the original data relevant to this manuscript is shown in Table $\mathbf{S} 2$ and accompanying figure. The $T_{C}$ of 
different strains obtained by TLVM [10] shows a considerable standard deviation. It is important to point out that due to the random variation of the $T_{C}[14]$ the standard error in this assay is due to an inherent property of the cells and not to experimental variability. The limitation of single cell measurement of the $\mathrm{T}_{\mathrm{C}}$ might be solved by technological improvement that will allow to measure huge number of events to reach statistical significance of the $\Delta T_{C}$ between two cell populations. The accompanying figure in Table $\mathbf{S 2}$ shows that if we plot the $\mathrm{T}_{\mathrm{C}}$ (media $\pm \mathrm{SD}$ ) for three different strains (real experimental data from [10], Table IV therein) it will be difficult to determinate whether those differences are real or not. Thus, even measurement of $T_{C}$ in single cell gives a significant standard error [10] that limits the resolution of the method. Therefore, analysis of individual cells does not solve the limitations of MsBCP.

In principle, the main limitation to measure small $\Delta \mathrm{T}_{\mathrm{C}}$ between two cell populations is the standard error of the measured endpoint due to inherent properties of the cell and/or experimental variability. To overcome this limitation, this manuscript proposes a strategy based in Co-Culture + Dilution and Propagation (CCDP method) of two unsynchronized cell strains that would allow the detection of minimal $\Delta \mathrm{T}_{\mathrm{C}}$ between two cell types. In this approach, the number or percentage of cells for each strain is measured as the endpoint variable. Conceptually, this strategy (due to the use of cell populations) minimizes the biological variability (by averaging a significant number of cells) and simultaneously (due to the series of dilution and propagation) "separates" the difference of the measured endpoint used to discriminate between two cell populations. This "separation" is made by progressively increasing the ratio $\mathrm{N}_{\mathrm{E} /} / \mathrm{N}_{\mathrm{C}}$ (number of the experimental cell/number of the control cells) after each round of dilution and propagation. In statistical terms, it increases the distance between the media of two different groups and makes it easy to be able to reach statistical significances even when the actual $\Delta \mathrm{T}_{\mathrm{C}}$ of two strains are minimal regardless of the expected experimental variation (Standard error). The only requirement for this strategy to be used in the laboratory is to quantitatively discriminate the percentage (or number) of cells (endpoint measured) of each sub-populations when cells are co-cultivated.

\section{METHODS}

\section{Simulation of an Idealized Experiment}

\section{Assumptions}

1) Cell number in co-cultures increases independent of each other following classical exponential growth (See glossary),

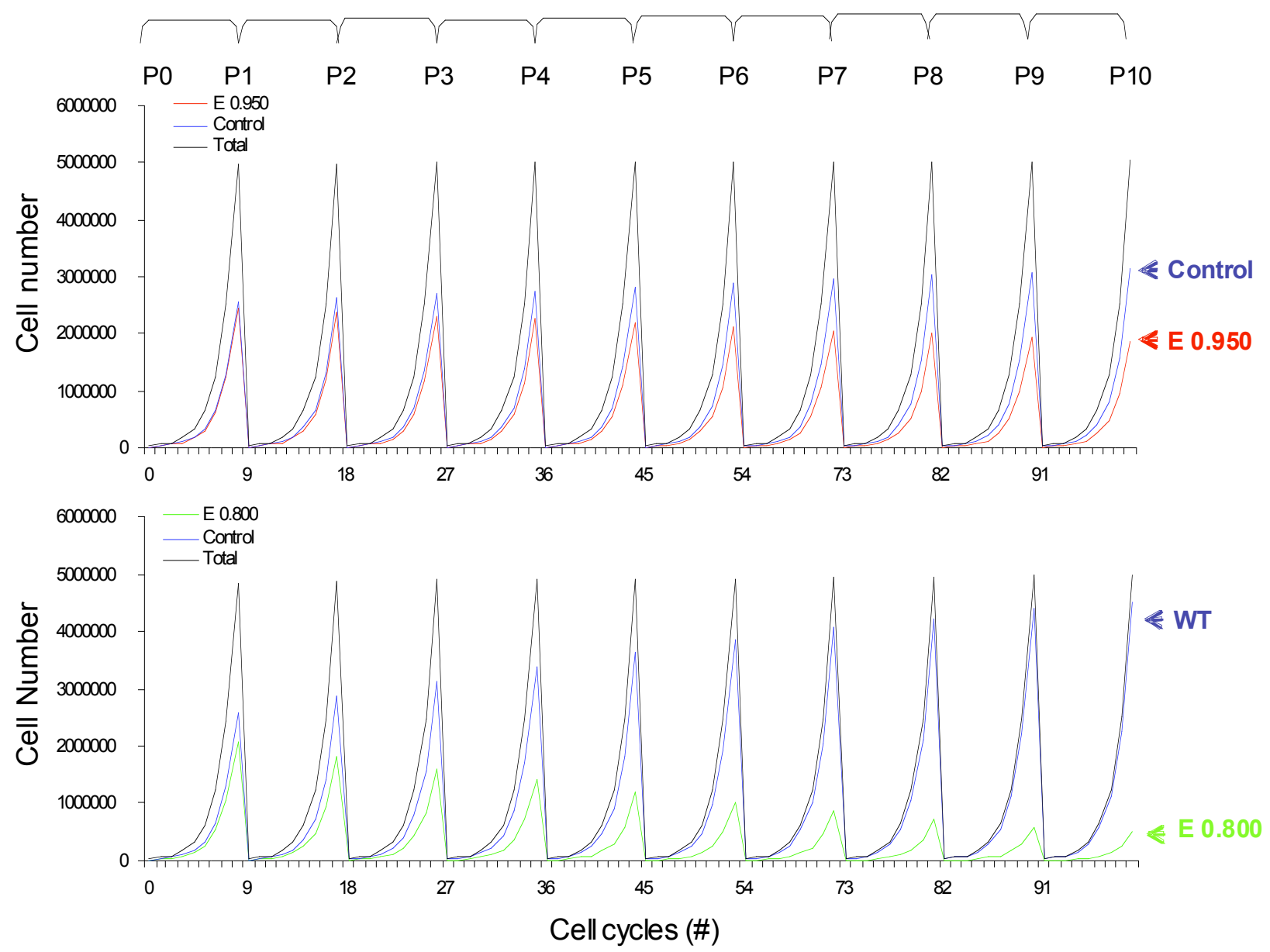

Fig. (1). Simulation of the CCDP method comparing Control versus E 0.950 strain (Top) and control versus E 0.800 strain (Bottom). P0 P10 denote the number of passages. Increase in cell number at each passage was simulated using classical exponential growth equation (See Glossary). 
2) No loss of cells occurs during the assay.

The CCDP method is based in 1) Initial co-cultivation of both strains (Passage 0 ) at a 1:1 ratio $\left(\mathrm{N}_{\mathrm{E} /} / \mathrm{N}_{\mathrm{C}}=1\right)$, 2) at least 10 cycles of dilution and propagation for 6-10 cell divisions (Passages 1-10). 3) Sample collection and storage at each passage before dilution. 4) Determination of the number of control and experimental cells for each collected samples (Passage 0-10).

Virtual experiments were performed using a virtual control strain with a $\mathrm{T}_{\mathrm{C}}=3 \mathrm{hr}(180 \mathrm{~min})$ and experimental strains $\left(\mathrm{E} 0.999-0.800, \mathrm{~T}_{\mathrm{C}}\right.$ ranging from $=180.180-225$ $\mathrm{min})$. For all simulations $2,500,000$ cells of each strain were mixed in a final $10 \mathrm{ml}$ volume, 2) a $40 \mu \mathrm{l}$ aliquot $(20,000$ cells) was immediately diluted into a final $10 \mathrm{ml}$ volume and allowed to propagate while the rest of the cells were collected and stored (Passage \#0). When the cell density reached $\sim 500,000$ cells $/ \mathrm{ml}$ (close to the initial mixing approximately 8 cycles-), an aliquot of 20,000 cells were diluted in fresh $10 \mathrm{ml}$ culture media and allowed to propagate, the rest of the cells were collected and stored (passage \#1). This cycle was repeated to collect 10 passages.

\section{RESULTS}

A simulation of the above experiment with strain E 0.950 is shown in Fig. (1) top. It can clearly be appreciated that after each passage the cell number of the control strain $\left(\mathrm{N}_{\mathrm{C}}\right)$ increases gradually while at the same time, the cell number of E 0.950 strain $\left(\mathrm{N}_{\mathrm{E}}\right)$ decreases proportionally. The same experiment using E 0.800 shows more dramatic changes in the relative number of cells present in the culture (Fig. (1) bottom).

The changes in the $\mathrm{N}_{\mathrm{C}}$ and $\mathrm{N}_{\mathrm{E}}$ after each passage modify the $\mathrm{N}_{\mathrm{E}} / \mathrm{N}_{\mathrm{C}}$ ratio from 1:1 (P0) to 0.598 (P10) (Fig. 2 top). The progressive modification in the $\mathrm{N}_{\mathrm{E}} / \mathrm{N}_{\mathrm{C}}$ ratio after each passage allows to estimate the proliferation kinetics of both subpopulations. The same experiment using E 0.800 showed a more pronounced change in the $\mathrm{N}_{\mathrm{E}} / \mathrm{N}_{\mathrm{C}}$ ratio from 1:1 (P0) to 0.107 (P10) (Fig. (2) bottom).

The $\mathrm{N}_{\mathrm{E}} / \mathrm{N}_{\mathrm{C}}$ ratio is shown for all the E strains (E 0.999 to E 0.800 ) in Fig. (3). The $\mathrm{N}_{\mathrm{E}} / \mathrm{N}_{\mathrm{C}}$ ratio progressively decreases for each strain as the number of passage increases. Fig. (4) shows the $\mathrm{N}_{\mathrm{E}} / \mathrm{N}_{\mathrm{C}}$ ratio at passage \# 10 for all the experimental strain (E 0.999 to E 0.800). By comparing to the

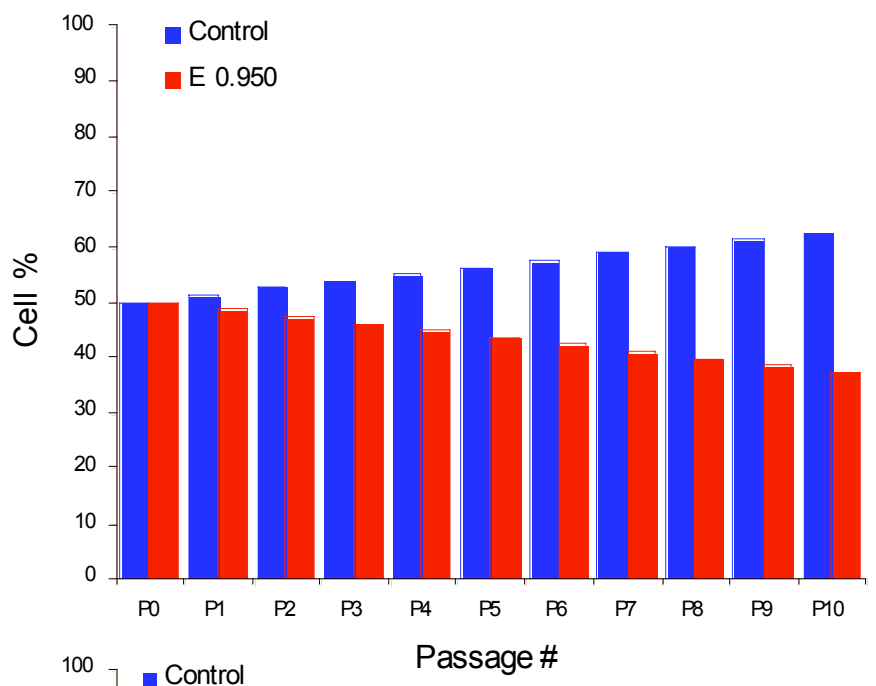

\begin{tabular}{|l|r|}
\hline \multicolumn{1}{|c|}{ Passage } & \multicolumn{1}{|c|}{$\mathrm{Ne} / \mathrm{Nc}$} \\
\hline P0 & 1 \\
\hline P1 & 0,95 \\
\hline P2 & 0,9025 \\
\hline P3 & 0,857375 \\
\hline P4 & 0,81450625 \\
\hline P5 & 0,77378094 \\
\hline P6 & 0,73509189 \\
\hline P7 & 0,6983373 \\
\hline P8 & 0,66342043 \\
\hline P9 & 0,63024941 \\
\hline P10 & 0,59873694 \\
\hline
\end{tabular}

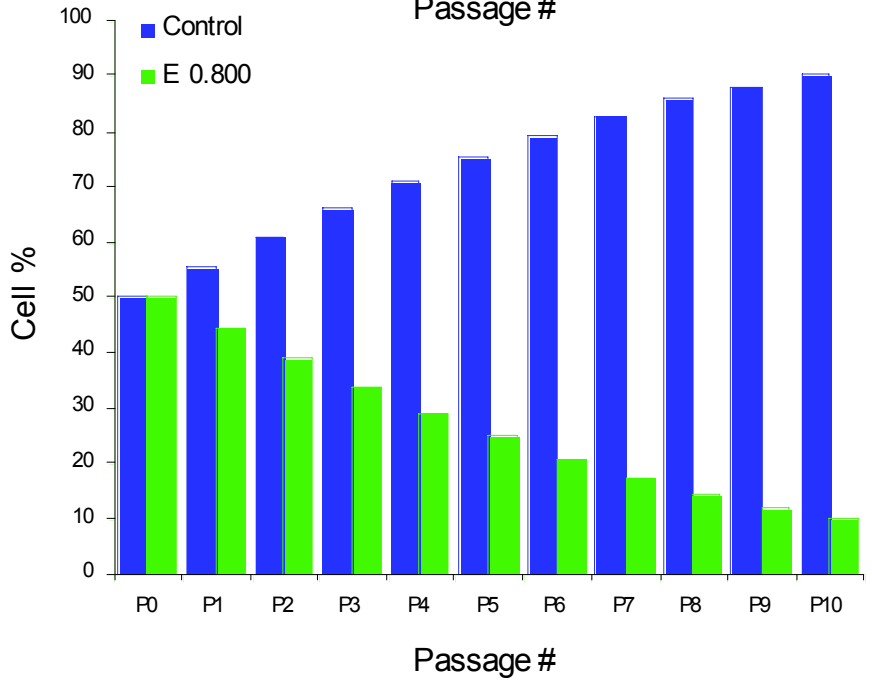

\begin{tabular}{|c|c|}
\hline Passage & $\mathrm{Ne} / \mathrm{Nc}$ \\
\hline P0 & 1 \\
\hline P1 & 0,8 \\
\hline P2 & 0,64 \\
\hline P3 & 0,512 \\
\hline P4 & 0,4096 \\
\hline P5 & 0,32768 \\
\hline P6 & 0,262144 \\
\hline P7 & 0,2097152 \\
\hline P8 & 0,16777216 \\
\hline P9 & 0,13421773 \\
\hline P10 & 0,10737418 \\
\hline
\end{tabular}

Fig. (2). Quantitative determination of the percentage of cell after each passage for the virtual experiments from Fig. (1): Control versus $\mathrm{E}$ 0.950 (Top) and control versus E 0.800 strains (Bottom). The table at the right of each figure shows the progressive changes in the $\mathrm{N}_{\mathrm{E}} / \mathrm{N}_{\mathrm{C}}$ ratio after each passage. See text for details. 


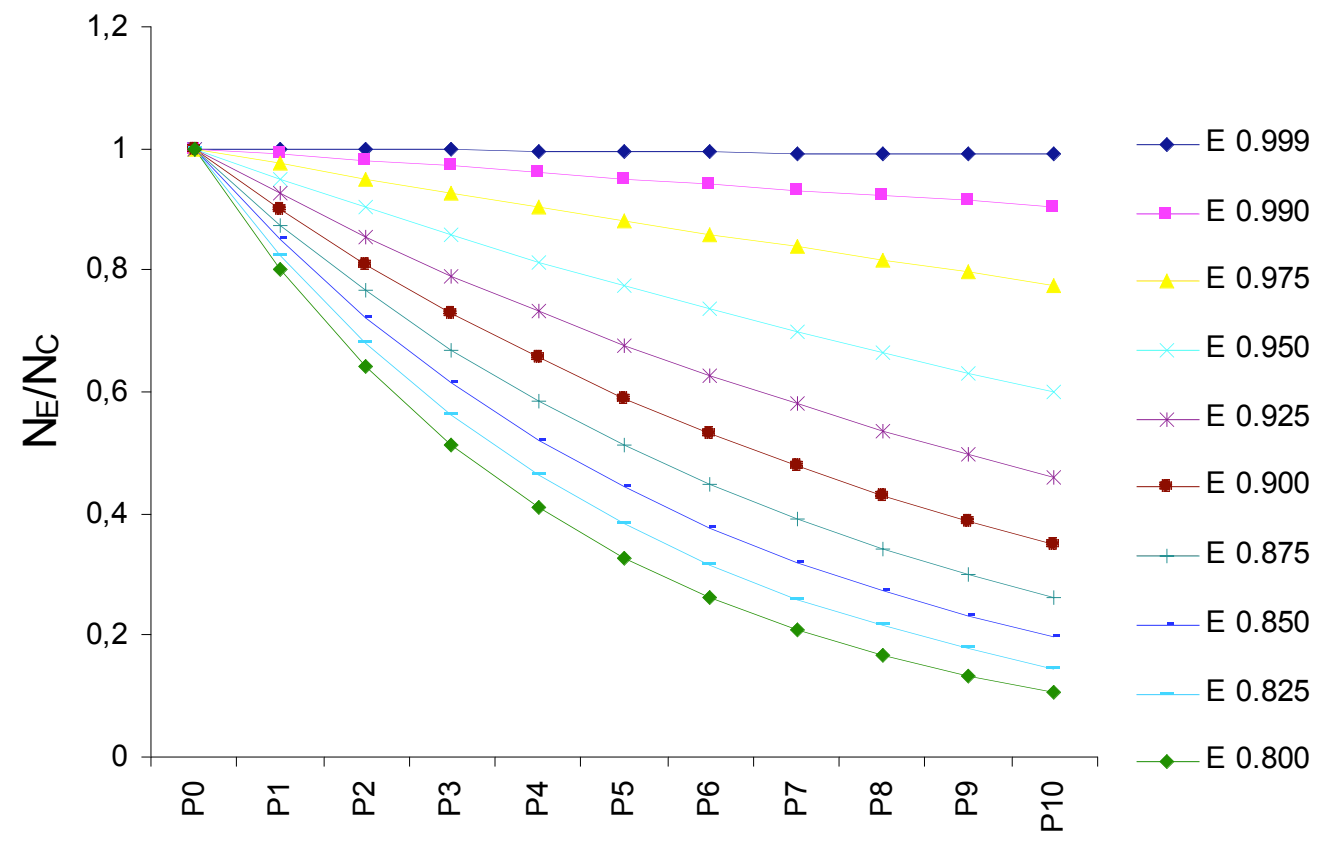

Fig. (3). $\mathrm{N}_{E} / \mathrm{N}_{\mathrm{C}}$ ratio for control versus 10 different experimental strains with different $\mathrm{RT}_{\mathrm{C}}(\mathrm{E} 0.999$ to E 0.800) plotted against passage number.

$\mathrm{N}_{\mathrm{E}} / \mathrm{N}_{\mathrm{C}}$ ratio at passage \# 1 it can easily be appreciated that the CCDP strategy "modifies" the $\mathrm{N}_{\mathrm{E}} / \mathrm{N}_{\mathrm{C}}$ ratio (endpoint variable measured), that depends on small differences in the length of the cell cycle, at values that can be quantitatively measured with sensitivity enough to detect minimal differences. Comparing control vs. all different strains
(E 0.999 - E 0.800) and assuming an experimental variation of $10 \%$ for all measured endpoint the CCDP method shows that it will sensitive enough to resolve cell with $\mathrm{RT}_{\mathrm{C}} \leq 0.975$ (Fig. 4). Higher resolution can be obtained by increasing the number of passages.
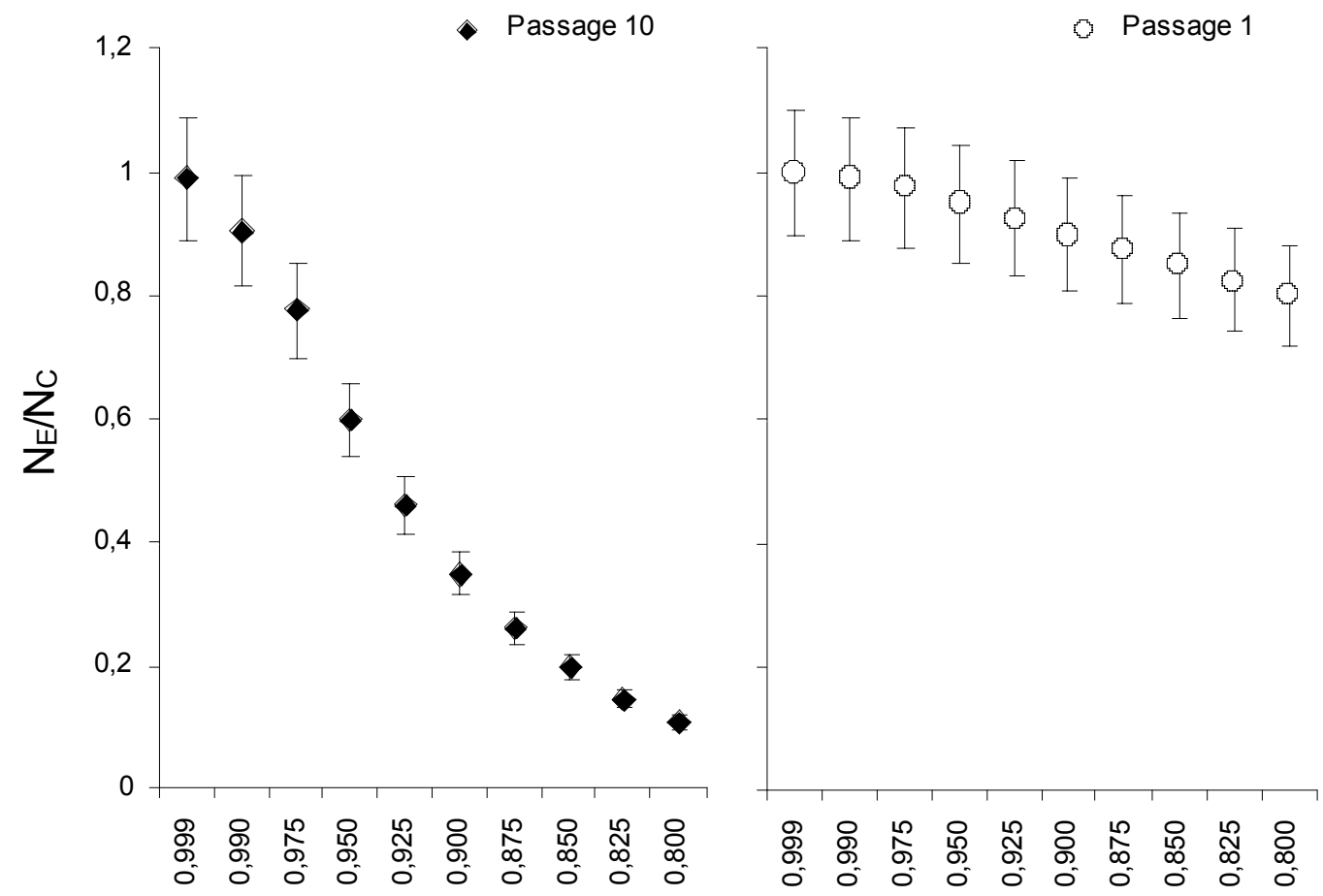

Fig. (4). Theoretical resolution of the CCDP method at passage 10 compared to passage 1 (similar to the resolution of current alternative methods. $\mathrm{N}_{\mathrm{E}} / \mathrm{N}_{\mathrm{C}}$ ratio at passage \#10 for all experimental strains with different $\mathrm{RT}_{\mathrm{C}}(0.999$ to 0.800$)$ (Left panel). $\mathrm{N}_{\mathrm{E}} / \mathrm{N}_{\mathrm{C}}$ ratio at passage \#1 for all experimental strains with different $\mathrm{RT}_{\mathrm{C}}(0.999$ to 0.800$)$ (Right panel). 


\section{DISCUSSION}

The CCDP strategy depends on the accurate quantification of each subpopulation (absolute numbers or percentage) present in a cell culture. The ideal variable for the quantification of the percentage of control and experimental cells present in a co-culture system (endpoint variable measured) must fulfil few essential requirements: 1) should be proportional to the number of cells in the culture 2) should be able to faithfully discriminate the percentage of each cell subpopulation. In practice, it is reasonable to assume that the ideal marker is DNA with a polymorphism (restriction site, insertion or deletion) that can be accurately measured by quantitative PCR to distinguish both subpopulations. In nature, components of the cell cycle are often mutated in cancer cells and experimentally, cells lines are transformed in order to recapitulate these mutations (or create others) to understand the mechanism of cell cycle control in normal and neoplastic cells. These mutations can affect the $T_{C}$ but at present are difficult to measure using current methods. The CCDP strategy can be used in available -transformed- cell lines that already have DNA polymorphisms compared to the parental strain to detect small differences in the $\mathrm{T}_{\mathrm{C}}$ caused by a particular mutation. When required, cell lines can also be specifically transformed creating polymorphism for this specific purpose to study genes of interest. The CCDP approach is ideal for non-adherent cells with relatively short $\mathrm{T}_{\mathrm{C}}$ such as yeast and ciliates. These model organisms are very useful to dissect genetic determinant of the cell cycle. The CFSE staining method [13] is the only one that allows the monitoring of cultures for multiple cell cycles and detects slower or faster growing sub-populations in culture [15]. The method is based in initial labelling of cells and quantification of CFSE for up to ten generations by flow cytometry. Since the CFSE method uses only one cycle of propagation the resolution is comparable to the CCDP method at passage \#1 and will not allow the detection of small $\Delta \mathrm{T}_{\mathrm{C}}$. (Fig. 4).

In summary, a method to evaluate small differences in the $\mathrm{T}_{\mathrm{C}}$ will be an important tool to gain mechanistic insight into the regulation of the length of the cell cycle and would have broad applications in biology and medicine. The application of the CCDP strategy to cell lines carrying spontaneous or experimentally-induced polymorphism will help to identify factors (e.g. genes, pathways) important for the fine regulation of the length of the cell cycle and it will expand our knowledge on the mechanism of several diseases and development.

\section{SUPPLEMENTARY MATERIAL}

Supplementary material is available on the publishers Web site along with the published article.

\section{GLOSSARY}

Cell cycle length

$\left(\mathrm{T}_{\mathrm{C}}\right)$

Relative $\quad \mathrm{T}_{\mathrm{C}}, \quad=\quad$ The ratio between the $\mathrm{T}_{\mathrm{C}}$ of a $\left(\mathrm{RT}_{\mathrm{C}}\right) \quad$ control and a "experimental" strain. For example if a control strain has a $\mathrm{T}_{\mathrm{C}}=3 \mathrm{~h}$ and the experimental strain $\mathrm{T}_{\mathrm{C}}=3.5 \mathrm{hr}$, $\mathrm{RT}_{\mathrm{C}}=0.857$. For this paper the $\mathrm{RT}_{\mathrm{C}}$ will be used to denote the $\mathrm{T}_{\mathrm{C}}$ of experimental (E) strains: e.g., E 0.857 will be a strain that compared to a normal strain with a $T_{C}=3 \mathrm{~h}$ has a $T_{C}=3.5 \mathrm{hr}$. The advantage of using $\mathrm{RT}_{\mathrm{C}}$ is that one becomes independent of the $\mathrm{T}_{\mathrm{C}}$ value (in hours or minutes) of the strain.

Cell cycle length $=\quad$ The difference in time of the cell Difference $\left(\Delta \mathrm{T}_{\mathrm{C}}\right)$

Resolution cycle length $\left(T_{C}\right)$ between two strains.

$=\quad$ The minimal difference between the length of the cell cycle $\left(\Delta \mathrm{T}_{\mathrm{C}}\right)$ of two strains that can be detected by a method.

Exponential growth equation

$\mathrm{N}_{\mathrm{T}}=\mathrm{N}_{0}\left(2^{\text {Tx RTC }}\right)$ where $\mathrm{N}_{\mathrm{T}}=$ Cell number at time $\mathrm{T}$; $\mathrm{T}=$ Time expressed as cell cycle number; $\mathrm{N}_{0}=$ Initial number of cells in the culture; $\mathrm{RTC}=$ relative $\mathrm{T}_{\mathrm{C}}(1$ for control strain).

\section{ACKNOWLEDGEMENT}

This work was supported by grants from the Swedish Research Council and the Karolinska Institute. The author declares no competing interest.

\section{REFERENCES}

[1] Alexiades MR, Cepko C. Quantitative analysis of proliferation and cell cycle length during development of the rat retina. Dev Dyn 1996; 205: 293-307.

[2] Blumenthal AB, Kriegstein HJ, Hogness DS. The units of DNA replication in Drosophila melanogaster chromosomes. Cold Spring Harb Symp Quant Biol 1974; 38: 205-23.

[3] Caviness VSJ, Goto $\mathrm{T}$, Tarui $\mathrm{T}$, et al. Cell output, cell cycle duration and neuronal specification: a model of integrated mechanisms of the neocortical proliferative process. Cereb Cortex 2003; 13: 592-8.

[4] Flickinger RA, Miyagi M, Moser CR, Rollins E. The relation of DNA synthesis to RNA synthesis in developing frog embryos. Dev Biol 1967; 15: 414-31.

[5] Spradling A, Orr-Weaver T. Regulation of DNA replication during Drosophila development. Annu Rev Genet 1987; 21: 373-403.

[6] Charvet CJ, Striedter GF. Developmental species differences in brain cell cycle rates between northern bobwhite quail (Colinus virginianus) and parakeets (Melopsittacus undulatus): implications for mosaic brain evolution. Brain Behav Evol 2008; 72: 295-306.

[7] Kornack DR, Rakic P. Changes in cell-cycle kinetics during the development and evolution of primate neocortex. Proc Natl Acad Sci USA 1998; 95: 1242-6.

[8] Ropolo M, Daga A, Griffero F, et al. Comparative Analysis of DNA repair in stem and nonstem glioma cell cultures. Mol Cancer Res 2009 7: 383-92.

[9] Cai L, Hayes NL, Nowakowski RS. Local homogeneity of cell cycle length in developing mouse cortex. J Neurosci 1997; 17: 2079-87.

[10] Dawson KB, Madoc-Jones H, Field EO. Variations in the generation times of a strain of rat sarcoma cells in culture. Exp Cell Res 1965; 38: 75-84.

[11] Eidukevicius R, Characiejus D, Janavicius R, et al. A method to estimate cell cycle time and growth fraction using bromodeoxy- 
uridine-flow cytometry data from a single sample. BMC Cancer 2005; 5: 122 (Erratum in: BMC Cancer 2006; 2006: 2184).

[12] Hinchcliffe EH. Using long-term time-lapse imaging of mammalian cell cycle progression for laboratory instruction and analysis. Cell Biol Educ 2005; 4: 284-90.
[13] Lyons AB, Parish CR. Determination of lymphocyte division by flow cytometry. J Immunol Methods 1994; 171: 131-7.

[14] Shields R. Transition probability and the origin of variation in the cell cycle. Nature 1977; 267: 704-7.

[15] Schorl C, Sedivy JM. Analysis of cell cycle phases and progression in cultured mammalian cells. Methods 2007; 41: 143-50.

Received: April 02, 2009

Revised: May 23, 2009

Accepted: June 06, 2009

(C) Yakisich J. Sebastian; Licensee Bentham Open.

This is an open access article licensed under the terms of the Creative Commons Attribution Non-Commercial License (http://creativecommons.org/licenses/by$\mathrm{nc} / 3.0 /$ ), which permits unrestricted, non-commercial use, distribution and reproduction in any medium, provided the work is properly cited. 